\section{7. マイクロ・リーダー作業による疲労}

黑江敏治（電電公社医事研）

私ぞもの職域には，電話番号の案内をしている職場が あるが，ここでは，現在のところ，作業に電話番号簿が 用いられている。ところが，電話加入数の增加に伴な い，番号簿が膨大化したため，先の扱い方が困難になる とともに，案内に時間を要することが問題となってき た。そこで，マイクロ・リーダーを用いることが考党ら れ，その試作機械ができたが，この機会に，私どもは， 人体面に詨する影響を検討するため，つぎのような実験 的調査を行った。

調查時期, 場所, 対象 $:$ 昭和 37 年 9 月 13 日 28日, 地 万の中級電話局, 交換手 3 名

調查項目：1. 作業条件，2.フリッカー値, 3. 近点距離 4 . 血圧, 脈搏数, 5. 色名呼称，6. 連続反応時間， 7. アンケート (疲労自覚症, 疲労部位) 調查方法: 現在の案内台（現台）とマイクロ案内台 （マイク台）を比較対照する意味で，被検者を 1 日ず つ, ランダムに, 両案内台につか垠, 朰就ぞれの台に, 延4日就業する如く，スケジュールを組んだ。

調查結果：1）調查当時の作業条件は, 室温 $25^{\circ} \mathrm{C}$, 湿

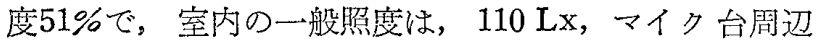
は，80Lx，であった。取扱作業量は，1.00/minで，雨 台で，汇とんど差買はなかった。作業者の眼の位置に特 ける照度は, 現台に正対した場合, $90 \mathrm{Lx}$, マイク台 $30 \mathrm{Lx}$ であった。

2)アンタートの結果から, 疲学自覚症の訴えが，一般 に高いことが注目された。（作業前 $24 \% ，$ 作業後 $32 \%$ )

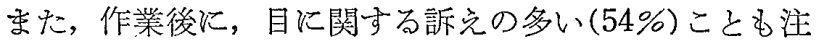
目された。

3)しかし近点距離は，現台，マイク台ともに作業前・ 後で，ほとんど変化を示さなかった。

4)脈搏数は, 両台とも作業後に若干減少する傾向を認 めたが，血圧は汪とんぞ変化を認めなかった。

5)連続反応時間は，作業後に，現台では短縮，マイク 台では延長を示した。

色名呼称沈，とくに変化を認めなかった。

6)フリッカー值の日間変動率は，現台 $-2.9 \%$,マイク 台一 $1.3 \%$ で, 現台の方が疲学が強いといら結果を得た。

208. オートメーション下作業における労働負担の研究 小泉 洌, 飯田尚治, 池田 弘, 中平成也, 助川秀弥, 高棳栄松 (北大衛生)
近時産慈の近代化に伴ない，オートメーションを取り 入れる職場が增加の一途をたどっているが，学衝衛生上 問題となる産業疲学に関して, 明確な考察がなされてい ない現状である。

我々は，某製鉄工場におけるオートメーション職場 で，責任を伴なら監視業務の勤番別の疲労調査を，5日 間にわ方り行ない，集中維持機能（TAF）を中心とし た諸種検查法で分析を試みた。

検查対象は, 監視業務甲番 (日勤午前 7 時 午後 3 時) 乙番（霄勤午後 3 時～午後 10 時), 丙番(夜勤午後 10 時 午前 7 時）及び事務系（午前 8 時〜午後 4 時まで普通勤 務)である。

検查項目は, 集中維持機能 (TAF), フリッカー值測 定法 $(\mathrm{FF})$, 皮屬空間閾值法 $(\mathrm{ES})$, 速続色名呼称法

(B1), 算点法 (Dc), 自覚症候及び自律神経系機能検 查法として，アシュネル試験，ケストナー皮膚寒冷刺戟 反応の 8 種検查法を実施した。

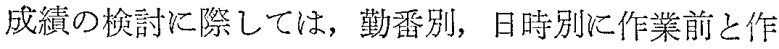
業後の実測値の平均を求め， FF，Es，Bl，Dc 飞関し ては，その平均俌からの各個人のちらばりの币を，標準 誤差でとら党，TAFに関しては，平均レベル（L）と 動摇の币（D）にもとついいて観察を試みた。

以上の成績について，勤番別飞钼察すると，まず平均 值の水準は，事務系と甲番とは潘ぼ同程度に高く，つい で丙，乙の順である。動摇の巾は，甲之事務系では，後 者は明らかに小さく，甲乙丙の此較では，乙が最大，っ ぎが甲で，丙が此較的小さいことが観察された。即ち一 般に疲労が大であると考党られている丙番（夜勤）上う むしろ乙番（霄勤）に叔てて，平均レベルも低く（即号 機能低下が大で)，か心動摇の巾が大であることが明ら が観察された。

季た普通職場とオートメーション職場との比較に执い て，勤務時間の大体等しい事務系之監視業務甲番之で は，平均レベルは汪添等しいが，動摇の内が，監視業茅 《有意差をもって大であり，作業内容の差によるストレ スの相違にもとづくものと考党られる。

\section{9. 産業疲労に関する一考察}

\section{一一高温下立ち作業について—}

井尻襄次郎, 北川幸司, 高梨恕寛, 藤木幸雄, 高田弘昭, 山本 学

（松下電器健康管理部）

わが企業に括活る疲労の実態を明らか炕する目的で， 筧35回産業医学会では顕微鏡使用作業者の視機能につい 